\title{
Lubou Hłazman
}

Witebski Państwowy Uniwersytet

im. P.M. Maszerawa

https://orcid.org/0000-0002-5209-3910

\section{Праблема самаідэнтыфікацыі асобы ва ўсходнеславянскім літаратуразнаўстве}

У сучасным літаратуразнаўстве прасочваецца выразная тэндэнцыя да актуалізацыі праблемы самаідэнтыфікацыі асобы: на ўзроўнях аўтара, наратара, літаратурнага персанажа. Пра гэта сведчыць значная колькасць даследаванняў, у якіх вывучаецца або фігуруе дадзеная з'ява. I гэта не дзіӱна, бо само пытанне асобаснай ідэнтычнасці абвастрылася $\ddot{y}$ посткаланіяльную эпоху. Феномен ідэнтычнасці аб'ектыўна прысутнічае $\breve{y}$ мастацкіх тэкстах: як чалавек праходзіць працэс уласнай ідэнтыфікацыі, так і літаратурны герой, паколькі персанаж з'яўляецца, па выразе М. Бахціна, завершаныл иэльим․ Аднак як правіла, заяўленая $\breve{y}$ назве сучасных літаратуразнаўчых даследаванняў ідэнтыфікацыйная праблема разглядаецца па-за спецыяльным тэарэтычным абгрунтаваннем; адсутнічае і каментарый да выкарыстойваемай тэрміналогіi. Маецца на ўвазе дапушчэнне, што паняцці «самаідэнтыфікацыя», «ідэнтычнасць», «самаідэнтычнасць» загадзя зразумелыя рэцыпіентам. Да таго ж, гэтыя паняцці набываюць кожны раз тое канкрэтнае значэнне, якое даследчыку зручна актуалізаваць, без дадатковых каментарыеў.

Самаідэнтыфікацыя асобы ў розных даследаваннях гуманітарнага профілю разглядаецца пераважна як складаны, абумойлены ў культурна-гістарычным плане, бесперапынны працэс набыцця тоеснасці

1 М.М. Бахтин, Автор и герой в эстетической деятельности, [в:] М.М. Бахтин, Эстетика словесного творчества, Москва 1986, с. 16-18. 
чалавека з самім сабой. Дыялектыка гэтага працэсу заключаецца $\ddot{y}$ немагчымасці такога самасупадзення (што паказана М. М. Бахціным $^{2}$, М. Хайдэггерам ${ }^{3}$ ), а таксама ў сумяшчэнні ў свядомасці чалавека сацыяльных і псіхалагічных складнікаў, якія адначасова і супрацьпастаўлены, і непарыўна звязаны паміж сабой.

Праблемы асобы, у тым ліку - крызіс яе самаідэнтыфікацыі, значна актуалізаваліся апошнім часам. Названы крызіс абвастрыўся у с сучасную эпоху росту сацыяльнай дынамікі ў посткаланіяльным свеце, у часы дэструкцыі і паніжэня статусу асобы у мастацтве постмадэрнізму. Усё гэта робіць праблематычным працэс захавання асобаснай цэласнасці, што вядзе да з'яўлення паняцця «паліфанічнай» («множнай») ідэнтычнасці (В. І. Жукава $\left.{ }^{4}\right)$. У падыходах прадстаўнікоў розных гуманітарных дысцыплін да пазначанай праблемы назіраюцца свае асаблівасці. Прадстаўнікі філасофскай думкі падыходзяць да праблемы больш тэарэтычна, з доляй універсалізму, упісваючы самаідэнтыфікацыю чалавека ў шырокі культурны і духоўны кантэкст. У той жа час даследчыкі псіхалагічнага напрамку схільныя менавіта да ўпарадкавання, класіфікацыі пытанняў па праблеме, часта звяртаюцца да пэўнай канкрэтнай групы людзей, канкрэтызуючы свае высновы. Іх даследаванні нярэдка маюць прыкладны характар. Прамежкавае становішча займаюць сацыялагічныя даследаванні, якія часта маюць эксперыментальную аснову.

Самаідэнтыфікацыя асобы літаратурнага героя - адна з эстэтычных уласцівасцей і характарыстык твора. Яна ў мастацкім тэксце існуе і заўсёды існавала гэтаксама ж аб'ектыўна, як самаідэнтыфікацыя чалавека ў рэальнай рэчаіснасці. А таму падлягае аналізу наройні з іншымі яго асобаснымі пазнакамі: характарам, партрэтам, сацыяльным статусам і г. д. Вядома, вывучэнне самаідэнтыфікацыі персанажа $\breve{y ~ т э к с ц е, ~ з ~ у л і к а м ~ м а с т а ц к а и ̆ ~ у м о и ̆ н а с ц і, ~ а у ̆ т а р с к а и ̆ ~ д у м к і ~ і ~ і н ш ы х ~}$ асаблівасцей мае выразную спецыфіку ў параўнанні з даследаваннямі у розных галінах гуманітарнага профілю. I тут важна размяжойваць паняцце самаідэнтыфікацыі і некаторыя характарыстыкі персанажаў, якія таксама маюць непасрэднае дачыненне да асобы героя і раскрываюць яго ўнутраную сутнасць. У літаратуразнаўстве найбольш

2 М.М. Бахтин, Проблемь поэтики Достоевского, Москва 1996.

3 М. Хайдеггер, Тождество и различие [online], http://www.gumer.info/bogoslov_ Buks/Philos/Heidegg/Togd_Razl.php. [доступ: 09.07.2017].

4 О.И. Жукова, Самость, ее типология и место в самоопределении человека, Томск 2010. 
распаўсюджаным аспектам вывучэння асобы героя з'яўляецца яго характар ${ }^{5}$. Аднак, калі характар уяўляе сабой сукупнасць пэўных асобасных рысаў, якія фарміруюцца часта даволі падсвядома і ўплываюць на паводзіны героя, самаідэнтыфікацыя героя ўключае пэўную рэфлексію паводле ўласнай асобы, яе становішча і свядомасці, а таксама звязана са свядомым вызначэннем асобай свайго месца ў свеце, абавязкова ўключае $\ddot{y}$ сябе адказ на пытанне: «хто я?». Акрамя таго, на сучасным этапе развіцця літаратуразнаўчай навукі шырокае распаўсюджанне атрымалі даследаванні канцэпцы асобы ў творчасці таго ці іншага аўтара (або групы аўтараў). Найперш у сувязі з гэтым феноменам варта ўзгадаць імёны беларускай даследчыцы Н. Л. Бахановіч ${ }^{6}$, рускага літаратуразнаўцы Ю. М. Паўлава7. Мяркуем, што канцэпцыя асобы - гэта сістэма поглядаў на чалавека, пэўны па-мастацку аформлены падыход да яго. Самаідэнтыфікацыя ж уключае самаапісанне, самапрэзентацыю персанажа ў тэксце, з'яўляючыся такім чынам поглядам героя на сябе, у адрозненне ад канцэпцы асобы - погляда на персанажа «зверху». Таму можна гаварыць пра самаідэнтыфікацыю як пра адзін са складнікаў, што адлюстройвае мастацкую канцэпцыю асобы.

Праблема самаідэнтыфікацыі асобы як самастойны аб'ект літаратуразнаўчага даследавання ва ўсходнеславянскіх даследаваннях пачала вылучацца толькі у апошнія дзесяцігоддзі. Яе актуалізацыя мае і агульныя - сацыякультурныя - перадумовы, і спецыфічныя, звязаныя са зменамі ў стаўленні да чалавека, што зрабіліся асабліва відавочнымі 3 усталяваннем у літаратуры некласічнай парадыгмы мастацкасці8.

Адным з папярэднікаў тэорыі ідэнтычнасці ў галіне літаратуразнаўства стаў знакаміты рускі філосаф М. М. Бахцін. Ён разглядаў праблему самаідэнтыфікацыі асобы як філасофскую катэгорыю ў кантэксце дыялагічнай канцэпцыі, адным з асноўных пастулатаў яго тэо-

5 У беларускім літаратуразнаўстве характар шырока даследуецца, напрыклад, у манаграфічных працах А. І. Белай: Людзі адной зямлі: тыпалогія $i$ паэтыка характарай у беларускай прозе першай трэчі ХХ стагоддзя, Баранавічь 2010; Герой. Асоба. Характар: Мастачкая персаналогія ў беларускай прозе першай трэчі ХХ стагоддзя, Баранавічы 2012.

6 Н.Л. Бахановіч, Канџэпџья асобь ў беларускай $і$ польскай прозе мальх жанраў на памежжы XIX-XX стст., Мінск 2012.

7 Ю.М. Павлов, Художественная концепиия личности в русской и русскоязычной литературе $X X$ века, Армавир 2004.

8 Тэрмін В. І. Цюпы (Теория литературных жанров: учеб. пособие для студ. учреждений высш. проф. образования, Москва 2011). 
рыі быў прынцып na-за-знаходжання9 ${ }^{9}$ Гэты прынцып працуе, між іншым, у дачыненні да чалавека, які ніколі не супадае з самім сабой ${ }^{10}$. Калі $\breve{y}$ натуральных навуках, па Бахціну, дзейнічае прынцып атаясамлівання «A=A», то у гуманітарным свеце (у тым ліку, мастацкім) тоеснасць пазначаецца як пераадоленне чужасці чужога без ператварэння яго у чыста сваёё. Паняцце «атаясамліванне» у Бахціна як філасофскі прынцып дарэчы прымяняць у дачыненні да самаідэнтыфікацы літаратурнага героя як «целого», якое адрозніваецца ад аўтарскай свядомасці і ніколі не супадае з ёй.

Аднак часцей за ўсё у літаратуразнаўчай думцы знаходзіць сваё адлюстраванне бахцінская канцэпцыя суаднесенасці аўтара і героя y ракурсе вывучэння пісьменніцкай свядомасці, што зрабіла значны ўплыў на развіццё тэорыі наратарскай ідэнтычнасці і самаідэнтыфікацыі для шэрагу расійскіх літаратуразнаўчых даследаванняў, сярод якіх працы А. У. Астахава ${ }^{12}$, Н. В. Барабанавай ${ }^{13}$, С. М. Есіна ${ }^{14}$.

3 пералічаных найбольш грунтойнай у тэарэтычным плане з'яўляецца праца Н. В. Барабанавай «Проблема идентичности образа литературного героя как проблема нарации» (2004). Даследчыца вывучае, якім чынам ствараецца цэласны вобраз раманнага героя у працэсе нарацыі, засноўваючыся на вучэннях М. М. Бахціна, П. Рыкёра, Ж. Лакана. У яе разуменні ідэнтычнасць героя складваецца праз ідэнтыфікацыю яго асобы аўтарам ці чытачом і мае на ўвазе яго характар, (...) спецыфіку ў якасиі героя ${ }^{15}$. Пры гэтым галоўнай мэтай устанаўлення ідэнтычнасці персанажа Н. В. Барабанава лічыць вызначэнне пэўных фармальных характарыстык твора: яго кампазіцыі, жанравай прыналежнасці. Мы ж даследуем самаідэнтыфікацыю асобы з пункту гледжання мастацкага сэнсу, ідэйнага плана твора, з мэтай вылучэння

9 М.М. Бахтин, Автор и герой в эстетической деятельности, [в:] М.М. Бахтин, Эстетика словесного творчества, с. 319, 433.

10 М.М. Бахтин, Проблемь поэтики Достоевского, Москва 1996, с. 266.

11 М.М. Бахтин, Автор и герой в эстетической деятельности, [в:] М.М. Бахтин, Эстетика словесного творчества, с. 433.

12 О.Ю. Астахов, Особенности самоидентификации личности в процессе художественного освоения мира в период культурного кризиса России конца XIX - начала $X X$ века, Кемерово 2000.

13 Н.В. Барабанова, Проблема идентичности образа литературного героя как проблема повествования, Самара 2004.

14 С. Н. Есин, Писатель в теории литературы: проблема самоидентификации, Москва 2005.

15 Н.В. Барабанова, Проблема идентичности образа литературного героя как проблема повествования, Самара 2004, с. 11. 
культурна-літаратурнай спецыфікі. Аднак тут варта ўлічваць нараталагічную накіраванасць працы Н. В. Барабанавай, бо яна вывучае пераважна не самаідэнтычнасць героя, а пэӱнае ўзаемадзеянне паміж аўтарам і героем, якое ствараецца у працэсе нарацыі. Акрамя таго, важным момантам у працы з'яўляецца вылучэнне даследчыцай уяўлення героя пра сябе як пра «я» і «інакавасць», а таксама праблем, звязаных з вызначэннем гэтых кампанентаў у творчым працэсе.

Увогуле, апрача адзінкавых выключэнняў, назіраецца ўстойлівая тэндэнцыя да ігнаравання тэарэтычнага абгрунтавання праблемы самаідэнтыфікацыі /ідэнтычнасці асобы. Так, існуе шэраг даследаванняў, якія закранаюць даследуемы феномен у творчасці асобных аўтараў. Сярод іх працы І. А. Якунінай ${ }^{16}$, А. С. Ярынай ${ }^{17}$, А. У. Бімаева ${ }^{18}$, К. Г. Дочавай ${ }^{19}$. Аднак названыя даследчыкі пазбягаюць канкрэтызацыі тэрміна, які на сённяшні дзень яшчэ патрабуе каментавання.

Асобную групу складаюць даследаванні менавіта нацыянальнага аспекту ідэнтычнасці асобы ў літаратурным творы (працы Г. В. Шапкінай ${ }^{20}$, С. А. Кулагіна ${ }^{21}$, С. В. Канчаковай ${ }^{22}$ ). На памежжы з лінгвістыкай даследуюцца моўныя сродкі адлюстравання самаідэнтыфікацы асобы у творы (I. М. Гасанава ${ }^{23}$ ). Акрамя таго, тэрмін «самаідэнтыфікацыя» ӱжываецца не толькі ў дачыненні да асобы, але і да цэлай літаратуры (даследаванне пошукаў самаідэнтыфікацыі рускай літаратурай другой паловы XIX стагоддзя ў працы I. В. Кудрашова $\left.{ }^{24}\right)$.

16 И.А. Якунина, Повествовательная идентичность в прозе А. Битова 1960-х 1970-x ге., Магнитогорск 2009.

17 Е.С. Ярина, Проблема самоидентификачии личности и особенности поэтической системы в романах Э. Елинек 1970-1980-х годов, Екатеринбург 2011.

18 А.В. Бимаев, Кризис самоидентификации героев в прозе А. П. Платонова, Абадан 2012.

19 К.Г. Дочева, Идентификачия личности героя в творчестве Сергея Довлатова, Орел 2004.

20 А.В. Шапкина, Романь А.К. Дойла "Бельй отряд" и “Сэр Найджел": проблема начиональной идентичности, Воронеж 2008.

21 С. А. Кулагин, Проблема национальной идентичности в прозе А. И. Куприна, Тамбов 2009.

22 С.В. Кончакова, Проблема начиональной идентичности в позднем творчестве Ч. Диккенса, Тамбов 2011.

23 И.М. Гасанова, Языковые средства изображения самоидентификачии личности в постколониальном романе $X X-X X I$ вв., Санкт-Петербург 2013.

24 И.В. Кудряшов, Русская литература в поисках духовной самоидентификации: начиональная жизнь в изображении П. И. Мельникова-Печерского, Н. С. Лескова, В. Г. Короленко, Г. И. Успенского, Волгорад 2008. 
Адзінкавыя літаратуразнаўчыя артыкулы тэарэтычнага характару па пазначанай праблеме ўсё ж існуюць. Перадусім гэта працы С. С. Імяхелавай ${ }^{25}$ і Л. А. Сафронавай ${ }^{26}$.

Даследаванне С. С. Імяхелавай «Проблема самоидентификации человека и ее осмысление в русской прозе второй половины XX века» фіксуе аснойныя прычыны духоўнага крызісу асобы, адлюстраваныя ў літаратуры гэтага часу. Тэарэтычная каштоўнасць артыкула заключаецца ў тым, што Імяхелавай удалося пазначыць праблему самаідэнтыфікацы асобы менавіта ў літаратурна-мастацкім сэнсе, разгледзець аналізуемы феномен як успрыняцце сябе персанажамі, створанымі аўтарамі. Адштурхойваючыся ад найбольш знакавых твораў, даследчыца вылучае дамінанты самаідэнтыфікацыйнага крызісу персанажаў у пазначаны перыяд. Сярод іх - страх жыцця, ілюзія самаідэнтычнасиі 27 як праблема сацыяльных, ідэалагічных стэрэатыпаў, экзістэн-

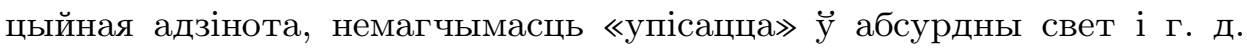
Пры тым, што пералічанае непасрэдна звязана з канкрэтнымі мастацкімі тэндэнцыямі ў рускай літаратуры пэўнага часу, многія з гэтых рысаў з'яўляюцца характэрнымі і для іншых мастацкіх тэкстаў.

Акрамя таго, С. С. Імяхелава вылучае «сапраўдную» i «несапрайдную» самаідэнтыфікацыю, пры гэтым, аднак, не паказваючы пэўнага балансу або крытэрыя, па якім адбываецца названае дзяленне (напрыклад, сумленне ці шчырасць у адносінах да сябе і іншых...). Таму уззнікае слушнае пытанне: што ёсць сапраўдная самаідэнтыфікацыля ${ }^{28}$ ? Калі сачыць за думкай даследчыцы, адчуваецца супрацьпастаўленне паміж нечым «сапраўдным», індывідуальным і навакольным светам; а у заключэнні артыкула і ўвогуле гучыць гімн перамозе асобы над часам, гісторыяй і соцыумам. Думаецца, што такое стаўленне да самаідэнтычнасці асобы ператвараецца ў нейкую - індывідуалісцкую - крайнасць, паколькі зусім не ўлічваецца магчымасць суіснавання з соцыумам, такой неабходнай «адкрытасці іншаму», пра якую пісаў

25 С.С. Имехелова, Проблема самоидентификации человека и ее осмьсление в русской прозе второй половинь $X X$ века, «Вестник Томск. госуд. педаг. ун-та», 2000, Вып. 6 (22).

26 Л.А. Софронова, О проблемах идентичности, [в:] Культура сквозь призму идентичности, Москва 2006.

27 С.С. Имехелова, Проблема самоидентификачии человека и ее осмьсление в русской прозе второй половины $X X$ века, «Вестник Томск. госуд. педаг. ун-та», 2000, Вып. 6 (22), с. 52 .

28 Tамсама, c. 54. 
M. М. Бахцін і без якой сапраўднай самаідэнтыфікацыі проста не атрымаецца. Тым не менш, даследчыцай закладзены асновы літаратуразнаўчага разумення самаідэнтыфікацыі асобы персанажа, пазначаны праявы несапрайднай самаідэнтыфікацыі.

Л. А. Сафронава $\ddot{y}$ артыкуле «О проблемах идентичности» (2006) разгледзела праблемы ідэнтычнасці і ідэнтыфікацыі суб'ектаў культуры ў больш шырокім, глабальным сэнсе, закранаючы пытанні сутнасці ідэнтыфікацыі героя, яе формы і эвалюцы ідэнтычнасцей мастацкага персанажа ў гісторыі культуры, спосабаў атаясамлівання персанажа чытачом і іншымі персанажамі, праблемы, звязаныя з ідэнтыфікацыяй тэкстаў і аўтарства і г. д.

Услед за назіраннямі папярэднікаў даследчыца сцвярджае зменлівы характар ідэнтычнасці і выводзіць гэтую ўласцівасць на агульнакультурны ўзровень, акцэнтуючы рознанакіраванасць ідэнтычнасці асобы ў мастацкіх тэкстах розных эпох: Праблемы ідэнтычнасиі складаючь істотны пласт у тэкстах культуры. Прачэс ідэнтыфікаиылі развіваециа $\check{y} i x$ у розных напрамках ${ }^{29}$. Гэтыя напрамкі вызначаюцца у залежнасці ад займаемай чалавекам пазіцыі, яго месца ў свеце (у адносінах да Бога, грамадства, да самога сябе). Так, напрыклад, у эпоху Асветніцтва суаднесенасць герояў з рэлігійнай этыкай душылася саџыяльнай ідэнтыфікаџыяйз ${ }^{30}$ у XIX стагоддзі найбольш прадуктыўным тыпам становіцца псіхалагічная ідэнтычнасць.

У аснове працэсу ідэнтыфікацыі, згодна з меркаваннем Л. А. Сафронавай, палягае апазіцыя «свой/чужы». 3 мэтай вызначыць сябе і іншага асобай выкарыстойваюцца розныя спосабы; у мастацкім тэксце ў якасці аснойных даследчыцай вызначаюцца і аналізуюцца два ўзаемазвязаныя матывы: пазнавання і ўтойвання (маска). Аналіз апошняга матыву і прыводзіць Сафронаву да ўвядзення у навуковы ӱжытак тэрміна «несапраўднай», або «ўскладненай ідэнтычнасці» (затрудненной идентичности) $)^{31}$, які яна грунтоўна даследуе таксама ў другім артыкуле - «Маска как прием затрудненной идентичности» (2006). Такім чынам, сцвярджаецца наяўнасць у героя праўдзівай (якую ён па нейкіх прычынах утойвае) і несапраўднай ідэнтычнасцяў (што знаходзіць праявы у у выглядзе маскі, у феномене двайніцтва). Даследчыцу пры-

29 Л.А. Софронова, О проблемах идентичности, [в:] Культура сквозь призму идентичности, Москва 2006, с. 10.

30 Тамсама, с. 11.

31 Л.А. Софронова, Маска как прием затрудненной идентификачии, [в:] Культура сквозь призму идентичности, Москва 2006, с. 343. 
ваблівае маскіраванне (якое як стварае магчьмасиі самаідэнтыфікаұы $i^{32}$, так і ўскладняе гэты працэс), яго супярэчлівасць. Атрымліваецца, што чалавек і ахойвае ўласную ідэнтычнасць ад іншых, і адначасова стварае перашкоды да самапазнання, бо губляе частку сябе пад маскай. Л. А. Сафронавай удалося прасачыць, як на працягу развіцця культуры мяняецца ўспрыманне маскі, яе функцыі. На змену апазіцыі «праўда/хлусня» прыходзіць усведамленне маскі як адной з мноства выяў асобы, што звязана з уяўленнем пра сумяшчэнне ў асобе мноства ідэнтычнасей.

Даследаванне самаідэнтыфікацыі асобы ў мастацкім тэксце грунтуецца на высновах па дадзенай праблеме, зробленых у розных галінах гуманітарных ведаў. У той жа час, літаратуразнаўцы, прызнаючы падпарадкаванне літаратурнага феномена самаідэнтыфікацыі ўніверсальным ідэнтыфікацыйным прынцыпам, спрабуюць улічваць у сваіх працах мастацкі кантэкст і законы мастацкай умоўнасці - каб вырашыць пытанні, што суадносяцца менавіта з задачамі аналізу літаратурнага працэсу. Так узнікаюць уяўленні пра спецыфічныя формы ідэнтычнасці і самаідэнтыфікацыйныя праблемы, уласцівыя для мастацкага тэксту: выкліканыя асаблівасцямі персанажа (або наратара) як фігуры, створанай аўтарам і ўспрымаемай чытачом. У гэтым плане выяўляюцца складанасці ўзаемадзеяння паміж пісьменніцкай і мастацкай ідэнтычнасцю, а таксама розныя аспекты ідэнтычнасці персанажаў у залежнасці ад сацыяльна-гістарычнай праблематыкі, пэўнага светапогляду ў тую ці іншую культурную эпоху. У той жа час, праблема самаідэнтыфікацыі асобы героя (звязаная з самаадчуваннем героя, з суаднесенасцю паміж тым, як персанаж сябе ўспрымае і кім насамрэч з'яўляецца, яго адпаведнасцю сацыякультурнаму асяроддзю i інш.), якую ўсё больш завастраюць пісьменнікі - i асабліва ў пераломныя часы, застаецца па-за межамі спецыяльнай увагі даследчыкаў беларускай і рускай нацыянальных літаратур. Між тым, адраджэникая задача сцвярджэння беларуса, беларускага светабачання, як слушна пазначае Л. Корань, працягвае паўставаць у беларускай мастацкай літаратуры як задача не архаічная, а сучасная ў поўным сэнсе гэтага слова $a^{33}$, што яшчэ больш актуалізуе неабходнасць самаідэнтыфікацыйных даследванняў асобы $\ddot{y}$ сучасным беларускім літаратуразнаўстве.

\footnotetext{
32 Тамсама, с. 347.

33 Л. Корань, Авангард і парадокс, [у:] Л. Корань, Цукровы пеўнік, Мінск 1996, c. 284 .
} 


\section{I T E R A T U R A}

Âkuninai. A., Povestvovatel'nâ̂ identičnost'v proze A. Bitova 1960-h - 1970-h gg., Magnitogorsk 2009 [Якунина И. А., Повествовательная идентичность в прозе А. Битова 1960-x - 1970-х ге., Магнитогорск 2009].

Ârina E. S., Problema samoidentifikacii ličnosti i osobennosti poètičeskoj sistemy $v$ romanah È. Elinek 1970-1980-h godov, Ekaterinburg 2011 [Ярина Е. C., Проблема самоидентификачии личности и особенности поэтической системь в романах Э. Елинек 1970-1980-х годов, Екатеринбург 2011].

Astahov O. Û., Osobennosti samoidentifikacii ličnosti v processe hudožestvennogo osvoeniâ mira v period kul'turnogo krizisa Rossii konca XIX - načala XX ve$k a$, Kemerovo 2000 [Астахов О. Ю., Особенности самоидентификации личности в прочессе художественного освоения мира в период культурного кризиса России конца XIX - начала XX века, Кемерово 2000].

Bahanovič N.L., Kancèpcyâ asoby ǔ belaruskaj i pol'skaj proze malyh žanraŭ na pamežžy XIX-XX stst., Mìnsk 2012 [Бахановіч Н.Л., Канцэпџыяя асобы $\check{y}$ беларускай $і$ польскай прозе мальх жанраў на памежжы XIX-XX $\mathrm{cmcm.,}$ Мінск 2012].

Bahtin M. M., Avtor i geroj v èstetičeskoj deâtel'nosti1, [v:] Bahtin M.M., Èstetikaslovesnogo tvorčestva, Moskva 1986 [Бахтин М. М., Автор и герой в эстетической деятельности, [в:] Бахтин М.М., Эстетика словесного творчества, Москва 1986].

Bahtin M. M., Problemy poètiki Dostoevskogo, Moskva 1996 [Бахтин М. М., Проблемы поэтики Достоевского, Москва 1996].

Barabanova N.V., Problema identičnostiobraza literaturnogo geroâ kak problema povestvovaniâ, Samara 2004 [Барабанова Н.В., Проблема идентичности образа литературного героя как проблема повествования, Самара 2004].

Bimaev A.V., Krizis samoidentifikacii geroev v proze A. P. Platonova, Abadan 2012 [Бимаев А. В., Кризис самоидентификачии героев в прозе А. П. Платонова, Абадан 2012].

Dočeva K. G., Identifikaciâ ličnosti geroâv tvorčestve Sergeâ Dovlatova, Orel 2004 [Дочева К. Г., Идентификачия личности героя в творчестве Сергея Довлатова, Орел 2004].

Esin S. N., Pisatel' v teorii literatury: problema samoidentifikacii, Moskva 2005 [Есин С. Н., Писатель в теории литературы: проблема самоидентификачии, Москва 2005].

Gasanova I. M., Âzykovyesredstva izobraženiâ samoidentifikacii ličnosti v postkolonial'nom romane XX-XXI vv., Sankt-Peterburg 2013 [Гасанова И. М., Языковье средства изображения самоидентификаиии личности в постколониальном романе $X X-X X I$ вв., Санкт-Петербург 2013]. 
Hajdegger M., Toždestvo i različie, [online], http://www.gumer.info/bogoslov_Buks /Philos/Heidegg/Togd_Razl.php, [dostup: 09.07.2017] [Хайдеггер M., Тождество и различие, [online], http://www.gumer.info/bogoslov_Buks/Philos /Heidegg/Togd_Razl.php, [доступ: 09.07.2017]].

Imehelova S. S., Problema samoidentifikacii čeloveka I ee osmyslenie v russkoj proze vtoroj poloviny $X X$ veka, «Vestniktomsk. gosud. pedag. un-ta» 2000, Vyp. 6 (22) [Имехелова С. С., Проблема самоидентификачии человека и ее осмьсление в русской прозе второй половины $X X$ века, «Вестник Томск. госуд. педаг. ун-та» 2000, Вып. 6 (22)].

Končakova S. V., Problema nacional'noj identičnostiv pozdnem tvorčestve $\check{C}$. Dikkensa, Tambov 2011 [Кончакова С. В., Проблема начиональной идентичности в позднем творчестве Ч. Диккенса, Тамбов 2011].

Koran' L., Avangard i paradoks, [u:] Koran' L., Cukrovy peǔnik, Mìnsk 1996 [Koрань Л., Авангард і парадокс, [у:] Корань Л., Цукровы пеўнік, Мінск 1996].

Kudrâšov I. V., Russkaâliteratura v poiskah duhovnoj samoidentifikacii: nacional'nâ̂ žizn'v izobraženii P. I. Mel'nikova-Pečerskogo, N. S. Leskova, V. G. Korolenko, G. I. Uspenskogo, Volgorad 2008 [Кудряшов И. В., Русская литература в поисках духовной самоидентификачии: начиональная жизнь в изображении П. И. Мельникова-Печерского, Н. С. Лескова, В. Г. Короленко, Г. И. Успенского, Волгорад 2008].

Kulagin S.A., Problema nacional'noj identičnostiv proze A. I. Kuprina, Tambov 2009 [Кулагин С.А., Проблема начиональной идентичности в прозе А. И. Куприна, Тамбов 2009].

Pavlov U. M., Hudožestvennâ̂ koncepciâličnosti v russkoj i russkoâzyčnoj literature XX veka, Armavir 2004 [Павлов Ю. М., Художественная концепиия личности в русской и русскоязычной литературе $X X$ века, Армавир 2004].

Sofronova L. A., Maska kak priem zatrudnennoj identifikacii, [v:] Kul'tura skvoz' prizmu identičnosti, Moskva 2006 [Софронова Л. А., Маска как прием затрудненной идентификачии, [в:] Культура сквозь призму идентичности, Москва 2006].

Sofronova L. A., O проблемах идентийности, [v:] Kul'tura skvoz' prizmu identičnosti, Moskva 2006 [Софронова Л. А., О проблемах идентичности, [в:] Культура сквозь призму идентичности, Москва 2006].

Šapkina A.V., Romany A. K. Dojla "Belyj otrâd" i "Sèr Najdžel": problema nacional'noj identičnosti, Voronež 2008 [Шапкина А. В., Романь А. К. Дойла "Бельй отряд" и "Сэр Найджел": проблема начиональной идентичности, Воронеж 2008].

Žukova O. I., Samost', ee tipologiâ i mesto vsamoopredelenii čeloveka, Tomsk 2010 [Жукова О. И., Самость, ее типология и место в самоопределении человека, Томск 2010]. 
S U M M A R Y

\section{THE PROBLEM OF PERSONALITY SELF-IDENTIFICATION IN EAST SLAVIC LITERARY CRITICISM}

In the article the phenomenon of self-identity as a subject of East Slavic literary criticism is discussed. Characteristic features of research on personality and its self-identification in the works of Belorussian and Russian scientists are traced. The author emphasizes the need to develop special theoretical literary works on the problem of self-identification due to its obvious significance and special attention writers' of fiction direct to it.

Key words: self-identity, Belarusian and Russian literary criticism, 'hindered' identity, character, personality concept. 